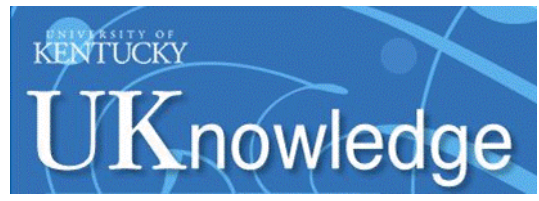

University of Kentucky

UKnowledge

$6-2010$

\title{
Diabetes and Physical Activity
}

Ingrid Adams

University of Kentucky, ingrid.adams@uky.edu

Follow this and additional works at: https://uknowledge.uky.edu/fcs_reports

Part of the Food Science Commons, and the Medical Education Commons

Right click to open a feedback form in a new tab to let us know how this document benefits you.

\section{Repository Citation}

Adams, Ingrid, "Diabetes and Physical Activity" (2010). Family and Consumer Sciences Publications. 3. https://uknowledge.uky.edu/fcs_reports/3

This Report is brought to you for free and open access by the Cooperative Extension Service at UKnowledge. It has been accepted for inclusion in Family and Consumer Sciences Publications by an authorized administrator of UKnowledge. For more information, please contact UKnowledge@lsv.uky.edu. 
FCS3-541

\section{Diabetes and Physical Activity}

Ingrid Adams, Nutrition and Food Science

$\mathbf{P}$ hysical activity plays an important part in the life of a person with diabetes. Being physically active helps you control your blood glucose and blood pressure. Taking part in physical activity provides protection against heart disease and stroke. Research shows that physical activity can even improve a person's mood and self esteem. In addition, physical activity is an excellent way to control excess weight.

\section{Types of physical activity}

There are several types of exercise.

- Endurance exercise-moderate or vigorous aerobic movement

- Strength exercises

- Balance exercises

- Stretching exercises

\section{How much physical activity should I do?}

The American Diabetes Association (ADA) developed a consensus statement with recommendations regarding exercise for patients with type 2 diabetes.

- Do 150 minutes per week or more of moderateintensity aerobic physical activity (brisk walk, jog, swim, bike)

- Do 75 minutes per week or more of vigorous aerobic exercise

- Physical activity distributed over at least 3 days per week, with no more than two consecutive days without physical activity

- Resistance exercise 3 times per week, targeting all major muscle groups (unless your health provider advises against it)

\section{Guidelines on Starting an Individualized Exercise Program}

Avoid strenuous activity if:

- Blood pressure higher than 180/100

- Active eye damage-proliferative retinopathy or recent laser therapy

- Recent foot problems or no feeling in extremities (hands and/or feet)

- Heart problems

- Over age 40

- Over age 30 and having had diabetes for more than 10 years

\section{Exercise plan}

Start with a little. If you haven't been doing any physical activity, talk to your health care team before you begin. Walking, working in the yard, and dancing are good ways to start. As you become stronger, you can add a few extra minutes to your physical activity. If you feel pain, slow down or stop and wait until it goes away. If the pain comes back, talk with your health care team right away.

\section{Goals of an exercise plan include:}

- Consistent exercise schedule

- Aerobic (jog, swim, bike) and anaerobic (weight lifting, push-ups) exercises

- Duration of 20 minutes/session or per day

- Intensity of 50-75 percent maximum heart capacity (220 - age $=100 \%$ capacity)

- If obese, burn or work off 700 to 2000 calories/week

\section{Being physically active helps you control your blood glucose and blood pressure.}


The ideal exercise plan is:

- Individualized, based on:

- Fitness level

- Age

- Weight

- Personal goals

- Medical history

- Cleared with your doctor.

Record the following details of your activities:

- Blood glucose values before and after 20 minutes of exercise

- Type, duration, intensity of exercise

- Any symptoms, such as pain dizziness, shortness of breath, low blood glucose or hypoglycemia.

Have your doctor explain to you which symptoms should be reported immediately and what to do about others that may occur.

\begin{tabular}{|l|l|l|}
\hline \multicolumn{3}{|c|}{ Physical activities } \\
\hline Moderate & Vigorous & Strength Training \\
\hline Walking & $\begin{array}{l}\text { Climbing } \\
\text { stairs or } \\
\text { hills }\end{array}$ & $\begin{array}{l}\text { Exercises using } \\
\text { exercise bands, weight } \\
\text { machines, hand-held } \\
\text { weights }\end{array}$ \\
\hline Dancing & $\begin{array}{l}\text { Shoveling } \\
\text { snow }\end{array}$ & $\begin{array}{l}\text { Callisthenic exercises } \\
\text { (body weight } \\
\text { provides resistance to } \\
\text { movement) }\end{array}$ \\
\hline Swimming & $\begin{array}{l}\text { Brisk } \\
\text { bicycling } \\
\text { up hill }\end{array}$ & $\begin{array}{l}\text { Digging, lifting, and } \\
\text { carrying as part of } \\
\text { gardening }\end{array}$ \\
\hline Water aerobics & $\begin{array}{l}\text { Digging } \\
\text { holes }\end{array}$ & Carrying groceries \\
\hline Jogging & Some yoga exercises \\
\hline $\begin{array}{l}\text { Aerobic exercise } \\
\text { classes }\end{array}$ & Some Tai Chi exercises \\
\hline $\begin{array}{l}\text { Bicycle riding } \\
\text { (stationary or on a } \\
\text { path) }\end{array}$ & & \\
\hline $\begin{array}{l}\text { Gardening (raking } \\
\text { and pushing a lawn } \\
\text { mower) }\end{array}$ & & \\
\hline Tennis & & \\
\hline Golf (without a cart) & & \\
\hline
\end{tabular}

\section{Remember}

- Some physical activity is better than no physical activity.

- Get some physical activity every day. It's better to walk 10 or 20 minutes each day than one hour once a week.

- Physical activity may be broken into 10-minute segments.

- Always check with your physician before you get involved in physical activity.

- Choose an activity you enjoy. The more fun it is, the more likely you will do it each day. It's also good to exercise with a family member or friend.

- If you have a chronic condition and cannot do 150 minutes of moderate physical activity a week then, be as physically active as you can.

\section{Safety Tips}

- Receive medical clearance befor starting a physical activity program.

- Understand whether and how your condition affects your ability to do regular physical activity safely.

- Carry glucose tablets or a carbohydrate snack with you in case you get hypoglycemia. Wear or carry an identification tag or card saying that you have diabetes.

- Drink plenty of water before, during, and after the activity.

- Check your blood glucose before, during, and after exercising. Don't exercise when your blood glucose is over $240 \mathrm{mg} / \mathrm{dl}$ or if you have ketones in your urine.

- Don't exercise right before you go to sleep because it could cause hypoglycemia during the night.

\section{Walking is a moderate type of activity with low risk of injury. If you have been inactive for many} years set as your goal: 3 hours to 3 hours and 30 minutes of walking a week. This is about 180 to 210 minutes. Start slowly and gradually work your way up to your goal.

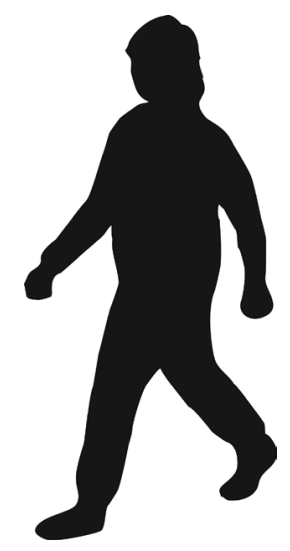




\section{9-week plan for physical activity}

\section{Weeks 1 and 2}

Start at a low level. Walk 10 minutes a day 3 days a week.

Divide the 10 minutes a day into two sessions.

For example, walk 5 minutes in the morning and 5 minutes in the evening.

Walk 30 minutes a week.

Walk one day and rest the next. For example, walk on Monday, rest on Tuesday; walk on Wednesday, rest on Thursday; walk on Friday; rest on Saturday.

\section{Week 3}

Add 5 more minutes of exercise a day. You will now be walking 15 minutes a day.

Your 15 minutes may be broken up into two sessions. For example, walk for 7 minutes in the morning and 8 minutes in the evening.

Walk 45 minutes a week.

Walk for 15 minutes on Monday, Wednesday, and Friday

\section{Week 4}

Add 5 more minutes of exercise a day. You will now be walking for 20 minutes a day.

Your 20 minutes may be broken up into two sessions. Walk for 10 minutes in the morning and 10 minutes in the evening

Walk 60 minutes a week.

Walk for 20 minutes on Monday, Wednesday, and Friday

\section{Week 5}

Add 5 more minutes of exercise a day. You will now be walking for 25 minutes a day.

Your 25 minutes may be broken up into two or even three sessions. Walk for 15

minutes in the morning and 10 minutes in the afternoon or vice versa.

Walk 75 minutes a week.

Walk for 25 minutes on Monday, Wednesday, and Friday

\section{Week 6}

Add 5 more minutes of exercise a day. You will now be walking for 30 minutes a day.

Your 30 minutes may be broken up into two or even three sessions. Walk for 10 minutes in the morning, 10 minutes in the afternoon, and 10 minutes in the evening. OR walk 15 minutes in the morning and 15 minutes in the evening.

Walk for 30 minutes on Monday, Wednesday, and Friday

\section{Week 7}

Add 5 more minutes of exercise a day. You will now be walking for 35 minutes a day.

Your 35 minutes may be broken up into two or even three sessions. Walk for 15 minutes in the morning, 10 minutes in the afternoon, and 10 minutes in the evening, OR walk for 20 minutes in the morning and 15 minutes in the evening.

Walk for 35 minutes on Monday, Wednesday, and Friday

\section{Week 8}

Add 5 more minutes of exercise a day. You will now be walking for 40 minutes a day.

Your 40 minutes may be broken up into two or even three sessions. Walk for 20 minutes in the morning and 20 minutes in the evening.

Walk 120 minutes a week Walk for 20 minutes on Monday, Wednesday, and Friday

\section{Week 9}

Add another day of activity on the weekend. Walk for 40 minutes on or throughout the weekend.

Your 40 minutes may be broken up into smaller activity times.

Walk 160 minutes a week

Gradually include activities such as hiking, biking, or an aerobic class. 


\section{Reference}

American Diabetes Association. Fitness. Accessed October 5, 2009 from http://www.diabetes.org/ food-nutrition-lifestyle/fitness.jsp.

National Diabetes Information Clearinghouse. What I need to know about physical activity and diabetes. Accessed May 10, 2009 from http://www. diabetes.niddk.nih.gov/dm/pubs/physical_ez/ index.htm.

Sigal, R.J., G.P. Kenny, D.H. Wasserman, C. Castaneda-Sceppa, and R.D. White. (2006). Diabetes. A consensus statement from the American Diabetes Association. Diabetes Care. 29:1433-1438.

U.S. Department of Health and Human Services. 2008 physical activity guidelines for Americans. Accessed January 15, 2009 from http://www. health.gov/paguidelines/ 